\title{
Biological Surfactants vs. Polysorbates: Comparison of Their Emulsifier and Surfactant Properties
}

In this work two biological surfactants, a cell-bound biosurfactant produced by Lactobacillus pentosus and a biosurfactant obtained from a fermented stream corn milling industry, were compared with two chemical surfactants (polysorbate 20 and polysorbate 80 ) in terms of surface tension reduction, critical micellar concentration (CMC), oil spreading and emulsifying capacity. Biological surfactants showed a similar ability to reduce the surface tension of water as polysorbates, which was in conformance with the results obtained in the drop collapse test. Regarding the ability to spread the oil on water, both biosurfactants produced similar results as polysorbates after $1 \mathrm{~h}$. However, after $24 \mathrm{~h}$, polysorbates and biosurfactant from corn stream were more effective than $L$. pentosus biosurfactant, producing greater free oil areas. Concerning the emulsifying activity, in terms of relative emulsion volume (EV), the biosurfactant produced from $L$. pentosus gave the best results $(E V=100 \%)$, after 1 day of emulsion formation, keeping this value over $50 \%$ after 15 days of emulsion formation; whereas polysorbates gave EV values lower than $50 \%$. The CMC values of the biosurfactant from corn stream and of polysorbates were closer in comparison with the CMC value of L. pentosus biosurfactant, observing that the characteristics and properties of the biosurfactant from corn stream are more similar to polysorbates than to $L$. pentosus biosurfactant. Thus, it could be speculated that biosurfactant from corn stream would be a good substitute for polysorbates.

Key words: Polysorbates, biosurfactants, oil spreading test, drop collapse test, emulsifier capacity

Biotenside gegen Polysorbate: Vergleich ihrer Emulgator-
und Tensideigenschaften. In dieser Arbeit wurden zwei Bio-
tenside, ein zellgebundenes Biotensid aus Lactobacillus pento-
sus und ein Biotensid, das dem fermentierten Strom einer Mais-
müllerei gewonnen wurde, mit den zwei chemischen Tensiden
Polysorbat 20 und Polysorbat 80 bezüglich der Reduktion der
Oberflächenspannung, kritischen Mizellenbildungskonzentra-
tion (CMC), Ölspreitung und Emulgierfähigkeit verglichen. Die
Biotenside können die Oberflächenspannung von Wasser ähn-
lich wie die Polysorbate reduzieren, was mit den Ergebnissen
des Tropfenkollapstests übereinstimmte. Hinsichtlich der Fähig-
keit, Öl auf Wasser zu spreiten, lieferten beide Biotenside nach
1 Stunde ähnliche Ergebnisse wie die Polysorbate. Nach 24 Stun-
den waren jedoch die Polysorbate und das Biotensid aus dem
Maisstrom wirksamer als das L. pentosus-Biotensid, indem grö-
ßere freie Ölflächen erzeugt wurden. Das aus L. pentosus herge-

Chemical Engineering Department, School of Industrial Engineering - Centro de Investigación Tecnológico Industrial (MTI), University of Vigo, Campus As Lagoas-Marcosende, 36310 Vigo, Spain.

Chemical Engineering Department, Barcelona East School of Engineering (EEBE), Polytechnic University of Catalonia (UPC)-Barcelona TECH, Campus Diagonal-Besòs, 08930 Barcelona, Spain.

Barcelona Research Center for Multiscale Science and Engineering, Campus Diagonal-Besòs, 08930 Barcelona, Spain. stellte Biotensid zeigte aufgrund des relativen Emulsionsvolumens $(E V=100 \%)$ nach einem Tag der Emulsionsbildung die beste Emulgieraktivität, wobei der EV-Wert nach 15 Tagen der Emulsionsbildung bei über $50 \%$ gehalten wurde. Die EV-Werte der Polysorbate erreichten weniger als $50 \%$. Die CMC-Werte des Biotensids aus dem Maisstrom und die der Polysorbate lagen im Vergleich zum CMC-Wert des $L$. pentosus-Biotensids näher beieinander, wobei beobachtet wurde, dass die Charakteristika und die Eigenschaften des Biotensids aus dem Maisstrom denen der Polysorbate ähnlicher sind als denen des L. pentosus-Biotensids. Daher könnte vermutet werden, dass das Biotensid aus Maisstrom ein guter Ersatz für die Polysorbate sein könnte.

Stichwörter: Polysorbate, Biotenside, Ölspreitungstest, Tropfenkollapstest, Emulgierfähigkeit

\section{Introduction}

Polysorbates are a family of surface-active compounds very often used in cosmetic, pharmaceutical and food industry to solubilize hydrophobic ingredients in water-based products [1-3]. They are non-ionic oily liquids derived from ethoxylated sorbitan, esterified with fatty acids. Although they are considered as non-toxic compounds, the use of hazard statements is recommended. For instance, the Classification, Labelling and Packaging (CLP) regulation of European Union assign to sorbitan monooleate, ethoxylated (Tween 80), with a CAS number of 9005-65-6, the following hazard statement codes: H412, H302, H312, H315, H319, H332, H412 related with eye and skin irritation as well as aquatic toxicity [4].

Since 1 June 2015, CLP is the only legislation in force in the EU for classification and labelling of substances and mixtures [5], revising and including the previous regulations about dangerous substances: Dangerous Substances Directive (67/548/EEC (DSD)), the Dangerous Preparations Directive (1999/45/EC (DPD)) and Regulation (EC) No 1907/ 2006 (REACH).

Nowadays there is an increasing demand for cost competitive and environment friendly alternatives to synthetic surfactants, attracting scientists all over the world to study the production of biological detergents, named biosurfactants, with enormous commercial and healthcare potentials in the current market with a higher ecological acceptance [6-11]. Biosurfactants can be produced by microorganisms, bacteria, yeast or fungi, by biotechnological processes, being more biodegradable than chemical surfactants [12-14]. Moreover, as they are composed by lipids, carbohydrates and/or proteins, they should be more biocompatible and less irritant than chemical surfactants and emulsifiers $[6,8]$. These biosurfactants can be extracellular or cell-bound [15-18]. For instance, Lactobacillus pentosus produces a cell-bound glycoli- 
popeptide biosurfactant that is able to reduce the surface tension of water in 23 units $[17,19]$. In previous works the biosurfactant produced by L. pentosus showed better emulsifier capacity than polysorbate 20 , when it was used as stabilizer agent of oil in water $(\mathrm{O} / \mathrm{W})$ emulsions containing rosemary oil [20].

Moreover, recently a biosurfactant extract from a fermented stream of corn milling industry has been obtained, which is able to reduce the surface tension of water in more than 30 units, and it is composed by a hydrophobic chain of fatty acids with similar composition to the lipopeptide biosurfactant produced from Bacillus subtilis [11, 18, 21].

However, before introducing these biological surfactants in pharmaceutical and cosmetic formulations, it is important to compare their surfactant and emulsifying activities with the most common surfactants used in these industrial sectors. From this point of view, polysorbates can be considered as one of the most employed families of surfactants in cosmetic formulations [20].

Hence, in this work polyoxyethylene (20) sorbitan monolaurate (Tween 20) and polyoxyethylene (20) sorbitan monooleate (Tween 80 ) were compared with two biological surfactants, obtained from controlled (L. pentosus biosurfactant) or spontaneous (biosurfactant from corn stream) fermentations. The comparison was in terms of surface tension capacity, using the drop collapse test and oil spreading test;

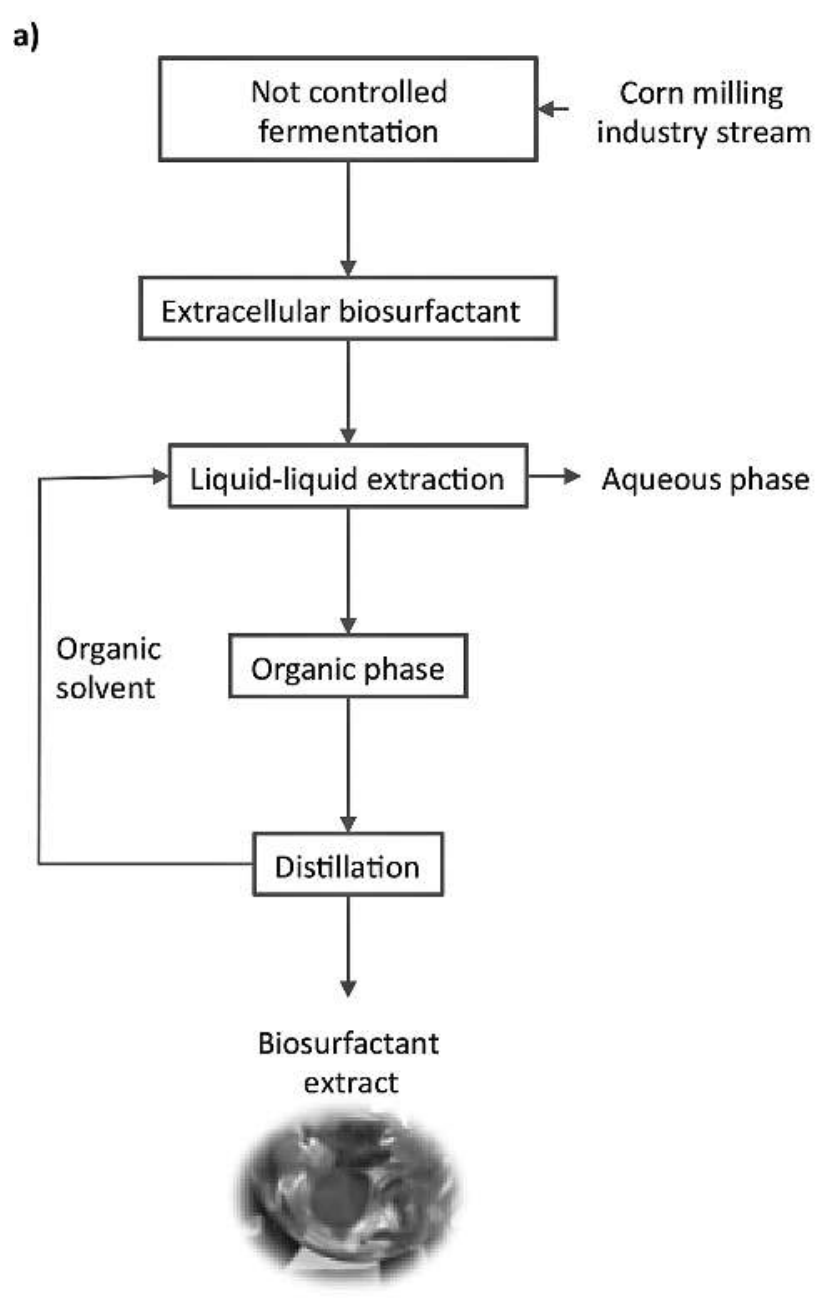

whereas their emulsifying activities were evaluated based on the capacity of the surfactants, under study, to stabilize oil/water rosemary emulsions.

\section{Materials and Methods}

2.1 Production of extracellular biosurfactant from corn stream (BS from CSL)

Corn steep liquor (CSL) was provided by Santa Cruz Biotechnology with a solid content of 50\% (LOT D2814). Then, $50 \mathrm{~g}$ were diluted in distilled water, achieving a concentration of $50 \mathrm{~g} / \mathrm{L}$. This solution was extracted with chloroform (CSL: $\left.\mathrm{CHCl}_{3} 1: 2 \mathrm{v} / \mathrm{v}\right)$, at $56^{\circ} \mathrm{C}$ for $1 \mathrm{~h}$, following the protocol established by Vecino et al. [21] and summarized in Fig. 1a. After that, the organic solvent was eliminated by vacuum distillation, using a rotatory evaporator R-210 (Buchi, Switzerland), and finally dissolved again in distilled water reaching a concentration about $0.9 \mathrm{mg} \mathrm{mL}^{-1}$, nine times above its critical micellar concentration (CMC).

\subsection{Production of cell-bound biosurfactant} from Lactobacillus pentosus (BS from L. pentosus)

An inoculum of $1 \mathrm{~mL}$ of $L$. pentosus CECT-4023T (ATCC8041) obtained from the Spanish Type Culture Collection

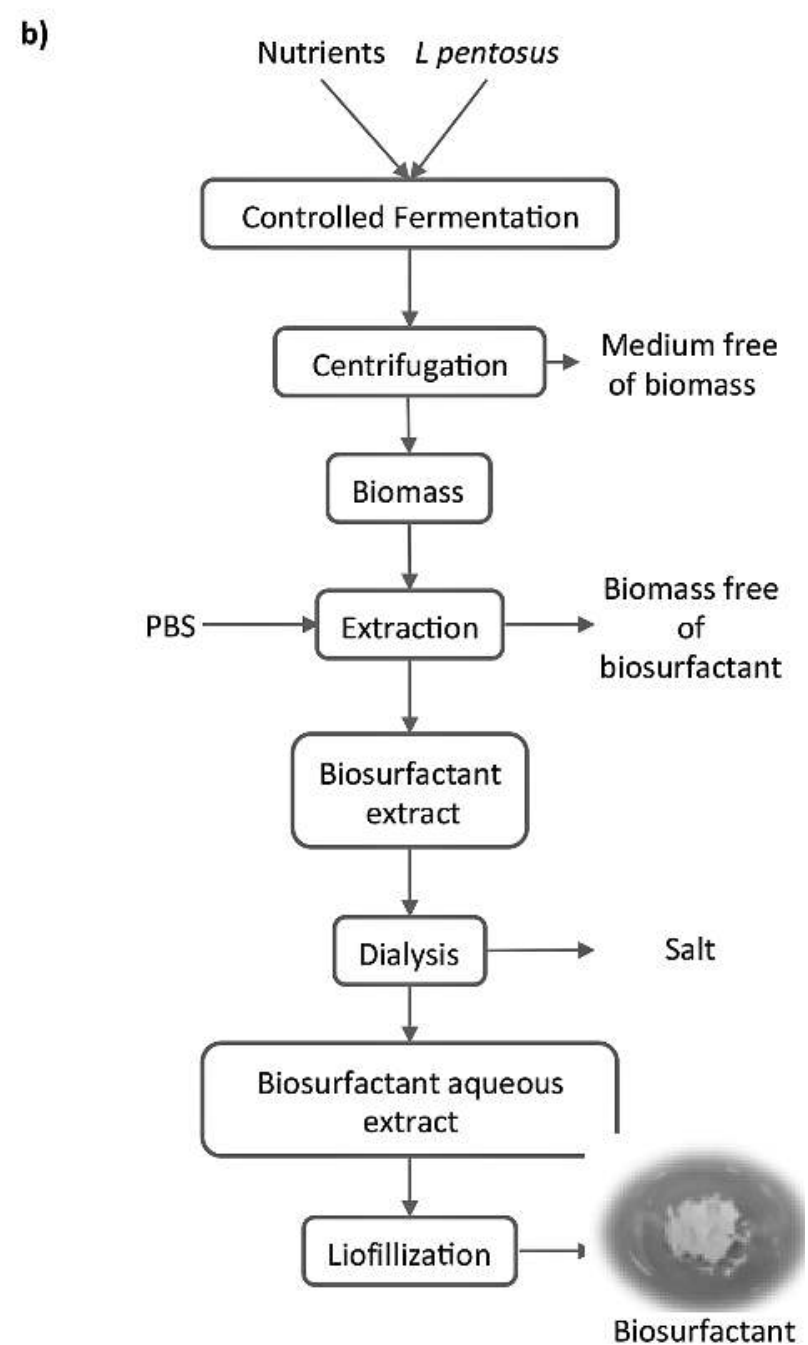

Figure 1 Overview of the biosurfactant extraction from corn steep liquor (a) and production of biosurfactant from L. pentosus (b). 
(CECT) (Valencia, Spain) was grown in a $250 \mathrm{~mL}$ Erlenmeyer flask with $100 \mathrm{~mL}$ of MRS Broth, named as its inventors (de Man, Rogosa and Sharpe), and previously autoclaved at $121^{\circ} \mathrm{C}$ for $15 \mathrm{~min}$. Then, it was incubated for $15 \mathrm{~h}$ at $31^{\circ} \mathrm{C}$, in a shaker at $200 \mathrm{rpm}$. When the fermentation finished, the biomass was separated by centrifugation, $30 \mathrm{~min}$ at $4{ }^{\circ} \mathrm{C}$ and $5000 \mathrm{rpm}$ (Rotina 380R, Hettich, Germany), and washed twice with distilled water in order to completely eliminate the culture medium. Next, the biosurfactant was extracted using $100 \mathrm{~mL}$ of phosphate buffer saline (PBS) $\left(10 \mathrm{mM} \mathrm{KH} \mathrm{PO}_{4} / \mathrm{K}_{2} \mathrm{HPO}_{4}\right.$ with $\left.150 \mathrm{mM} \mathrm{NaCl}\right)$ during $2 \mathrm{~h}$ at room temperature $\left(25^{\circ} \mathrm{C}\right)$. The biomass was separated again, while the supernatant was filtered using a polyvinylidene fluoride (PVDF) filter Stericup-GV $0.22 \mu \mathrm{m}$ (Millipore, Germany) in order to sterilize it. Then, it was subjected to a dialysis process against distilled water at $4{ }^{\circ} \mathrm{C}$ in a Cellu-Sep membrane (molecular weight cut-off 6000$8000 \mathrm{Da}$; Membrane Filtration Products, Inc., USA) for $48 \mathrm{~h}$. Finally, the biosurfactant was lyophilized using a lyophilizer Lyoquest 85Plus (Telstar, Spain), obtaining a white powder as it was shown in Fig. 1b, and dissolved in water reaching a concentration of $14.5 \mathrm{mg} \mathrm{mL}^{-1}$ (nine times above its CMC).

\subsection{Polysorbates}

Tween 20 and Tween 80 were supplied by Panreac (Spain) and Scharlab (Spain), respectively. In order to compare with biological surfactants, they were also prepared nine times up their CMC, so a solution of $0.540 \mathrm{mg} \mathrm{mL}^{-1}$ and $0.135 \mathrm{mg}$ $\mathrm{mL}^{-1}$ was prepared in distilled water for Tween 20 and Tween 80 , respectively [22].

\subsection{Surface-active properties characterization}

Biosurfactants (from L. pentosus and CSL) were subjected to various analyses for the purpose of establishing its surface tension capacity and CMC. The surface tension was measured with a tensiometer KRÜSS (K20 EasyDyne), using the Wilhelmy plate method. Several dilutions were prepared in order to determine the CMC of both biosurfactants. Above the CMC, the surface tension of a biosurfactant solution is constant and specific for each surfactant. Otherwise, below the CMC, the concentration of any active surface compound is directly proportional to its capacity to reduce the surface tension of water. In this way, for establishing this relationship, various solutions containing different biosurfactant extract concentrations were prepared. Measurements were made in triplicate, at room temperature, to increase the accuracy of the results.

\subsection{Color characterization}

Aqueous solutions containing biosurfactants and polysorbates nine times above their CMC were analyzed with a spectrophotometer Jasco V-650 (Jasco, Spain), obtaining the physical properties related with the color of the surface-active compounds under evaluation using Spectra manager software version 2 (Spectra Analysis) and applying the CIELAB color system.

\subsection{Emulsifier activity}

The emulsifying capacity was studied by mixing $2 \mathrm{~mL}$ of rosemary oil with $2 \mathrm{~mL}$ of an aqueous solution of Tween 20, Tween 80, BS from CSL or L. pentosus BS. Samples were stirred for 2 min, using a vortex (Velp Scientifica, Italy) and the volume of emulsion was measured after 1 day and 15 days, using a digital caliper (Format, Germany). Finally, the relative emulsion volume (EV, \%) and emulsion stability (ES, \%) were determined according to Portilla-Rivera et al. [19], using Equation 1 and 2, respectively.

$$
\mathrm{EV}(\%)=\frac{\text { Emulsion height } \times \text { Cross section area }}{\text { Total liquid volume }} \times 100
$$

$\mathrm{ES}(\%)=\frac{\mathrm{EV}_{\mathrm{t}}}{\mathrm{EV}_{0}} \times 100$

Where $\mathrm{EV}_{\mathrm{t}}$ is the emulsion volume after $\mathrm{t}$ days and $\mathrm{EV}_{0}$ is the emulsion volume at zero time (1 day).

\subsection{Drop collapse test}

For this assay, $10 \mu \mathrm{L}$ of different surface-active compounds were pipetted as a droplet onto parafilm [23]. The flattening of the droplet and the spreading on the parafilm surface were examined and in the case of the mentioned biosurfactant extracts compared with distilled water (as negative control), and Tween $20\left(0.540 \mathrm{mg} \mathrm{mL}^{-1}\right)$ and Tween 80 $\left(0.135 \mathrm{mg} \mathrm{mL}^{-1}\right)$ as chemical surfactants. The concentration of these surfactants was nine times their CMC. In this assay the biological surfactants under study were also investigated at different concentrations including nine times the concentration of their respective CMC, corresponding to $0.900 \mathrm{mg} \mathrm{mL}^{-1}$ and $14.5 \mathrm{mg} \mathrm{mL}^{-1}$ for the biosurfactant obtained from CSL and for the biosurfactant obtained from L. pentosus respectively. The drop collapse test is useful to confirm that higher droplet diameter supposes higher surfactant activity [24]. The diameter of the droplet was measured by a Digital-Caliper ABS (Format, Germany).

\subsection{Oil spreading test}

This assay was carried out in a Petri dish of $8.5 \mathrm{~mm}$ diameter, containing $20 \mathrm{~mL}$ of distilled water, overlaid with $160 \mu \mathrm{L}$ of a juniper oil extract provided by Gran Velada (Spain). Then, $80 \mu \mathrm{L}$ of the surfactants under evaluation were added and compared. Again, all of them were compared at concentrations nine times above their CMC. Moreover, biosurfactant from $L$ pentosus was evaluated at intermediated concentrations and the biosurfactant extract from CSL was also used pure (undiluted). The appearance of clear zones was observed after $1 \mathrm{~h}$ and $24 \mathrm{~h}$ and the area was also quantified twice using a Digital-Caliper ABS (Format, Germany) [24].

\section{Results and Discussion}

\subsection{Surface-active and color properties characterization}

Figure 1 shows the procedure used to obtain the biosurfactants under evaluation, as well as it is included a picture of both biological surfactants. As it can be observed, biosurfactant from CSL has an appearance similar to polysorbates, whereas biosurfactant extracted from $L$. pentosus cells is a white powder.

On the other hand, Table 1 includes the surface-active characteristics of the biosurfactants in comparison to Tween 20 and Tween 80. It can be observed that biosurfactant from CSL has a CMC closer to polysorbates than L. pentosus biosurfactant. 
This table also includes the colorimetric parameters for the biosurfactants and polysorbates studied, observing $L^{*}$ values of 100 in the case of polysorbates and 51 and 81.93 for biosurfactants from CSL and L. pentosus, respectively. These results are in concordance with other obtained in previous studies, in which the color properties of biosurfactant from CSL were determined in combination with different micas in order to obtain sunscreen formulations [25]. The $\mathrm{L}^{*}$ value represents one of the three axes in a spherical from of the CIELAB color system. The L* axis is associated with lightness, so that 100 means white and 0 means black. The color axes are based on the fact that a color can not be both red and green, or both blue and yellow, because these colors oppose each other. On each axis the values run from positive to negative. Therefore, the chromaticity indices $\mathrm{a}^{*}$ and $\mathrm{b} *$, are associated with changes in redness-greenness and in yellowness-blueness, respectively, so positive $a^{*}$ is red and negative $a^{*}$ is green, while positive $b^{*}$ is yellow and negative $b *$ is blue; both vary in the axes that from a plan orthogonal to $L^{*}$, and do not have specific numerical limits [26, 27].

Based on the $a^{*}$ and $b *$ values included in Table 1 , polysorbates are closer to green and blue, whereas biological surfactants are closer to red and yellow, observing that the color discrimination threshold of the human eye greatly differs from the range of color of CIELAB color system. The differences between $L^{*}, a^{*}$ and $b *$ can be useful at industrial scale for a more objective quality control and formula adjustment.

\subsection{Emulsifier activity}

Among the surfactants evaluated, the biosurfactant produced by L. pentosus gave better EV values, followed by Tween 80 and Tween 20, whereas the biosurfactant obtained from CSL gave lower emulsifier activity comparable to the results of the negative control (see Table 2). Therefore, $L$. pentosus biosurfactant gave EV values of $100 \%$, after 1 day, whereas Tween 80 and Tween 20 produced EV values be- tween 68.4-50.3\%; although the ES decreased by about 53.9-30.2\% depending on the surfactant, being the L. pentosus biosurfactant, which produced a highest ES reduction followed by Tween 80 and Tween 20. Biosurfactant from $L$. pentosus was the unique surfactant under evaluation that was able to keep the EV over $50 \%$ after 15 days of emulsion formation. These data are in accordance with a previous work reported by Vecino et al. [20], where it was observed that $L$. pentosus biosurfactant gave more stable emulsions than Tween 20. Figure 2 shows a picture of the rosemary

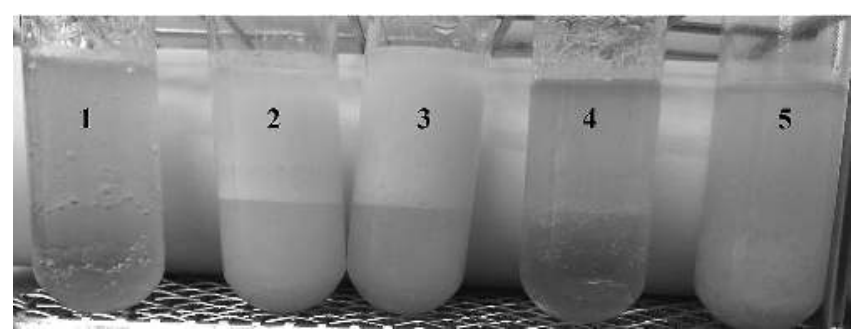

(a)

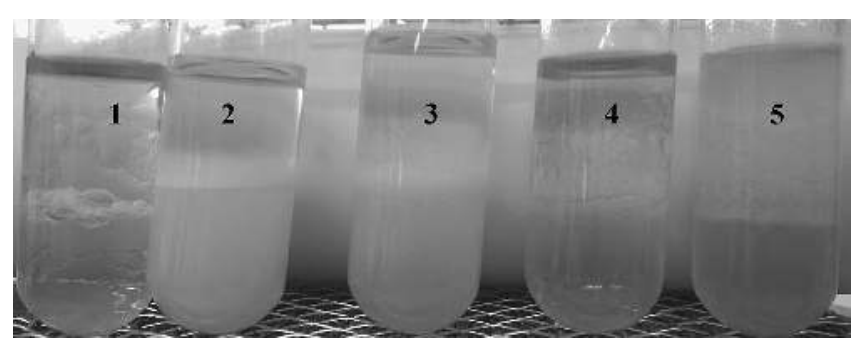

(b)

Figure 2 Emulsions obtained with water (1), Tween 20 at $0.540 \mathrm{mg} \mathrm{mL}^{-1}$ (2) Tween 80 at $0.135 \mathrm{mg} \mathrm{mL}^{-1}$ (3), BS from CSL at $0.900 \mathrm{mg} \mathrm{mL}^{-1}$ (4) and $\mathrm{BS}$ from $L$. pentosus at $14.5 \mathrm{mg} \mathrm{mL}^{-1}$ (5) after 1 day (a) and after 15 days (b)

\begin{tabular}{|c|c|c|c|c|c|}
\hline Compound & $\begin{array}{c}\mathrm{CMC} \\
\left(\mathrm{mg} \mathrm{mL}^{-1}\right)\end{array}$ & $\begin{array}{c}\text { ST reduction } \\
\text { units }\end{array}$ & L $^{*}$ & $\mathrm{a}^{*}$ & $\mathrm{~b}^{*}$ \\
\hline Tween 20 & 0.060 & 36 & 100.0 & -0.03 & -0.05 \\
\hline Tween 80 & 0.015 & 32 & 100.0 & -0.01 & -0.02 \\
\hline BS from CSL & 0.116 & 32 & 51.0 & 3.09 & 20.15 \\
\hline BS from L. pentosus & 1.610 & 28 & 81.9 & 0.13 & 4.56 \\
\hline
\end{tabular}

Table 1 Surface-active and color properties of chemical and biological surfactants evaluated

\begin{tabular}{|c|c|c|c|c|c|c|}
\hline Surfactant & $\begin{array}{l}\text { Concentration in } \\
\text { the experiments } \\
\left(\mathrm{mg} \mathrm{mL}^{-1}\right)\end{array}$ & $\begin{array}{c}\text { EV (\%) of } \\
\text { emulsions after } \\
15 \text { days }\end{array}$ & $\begin{array}{c}\text { ES (\%) of } \\
\text { emulsions after } \\
15 \text { days }\end{array}$ & $\begin{array}{l}\text { Drop diameter } \\
\text { in Drop collapse } \\
\text { test }(\mathrm{mm})\end{array}$ & $\begin{array}{l}\text { Clear zone in Oil } \\
\text { spreading test } \\
\left(\mathrm{cm}^{2}\right) 1 \mathrm{~h}\end{array}$ & $\begin{array}{l}\text { Clear zone in Oil } \\
\text { spreading test } \\
\left(\mathrm{cm}^{2}\right) 24 \mathrm{~h}\end{array}$ \\
\hline \multirow{3}{*}{$\begin{array}{l}\text { BS from } \\
\text { CSL }\end{array}$} & Pure extract & ND* & ND* & 5.5 & 56.8 & 56.7 \\
\hline & 0.90 & 0.0 & 0.0 & 4.4 & 12.5 & 28.3 \\
\hline & 0.50 & ND* & ND* & 4.2 & 0.0 & 0.0 \\
\hline \multirow{2}{*}{$\begin{array}{l}\text { BS from } \\
\text { L. pentosus }\end{array}$} & 14.50 & 49.2 & 49.2 & 4.9 & 14.6 & 14.6 \\
\hline & 7.25 & ND* & ND* & 3.9 & 7.1 & 9.6 \\
\hline Tween 20 & 0.54 & 27.1 & 53.9 & 4.8 & 16.5 & 40.6 \\
\hline Tween 80 & 0.135 & 30.1 & 43.9 & 3.9 & 10.5 & 39.3 \\
\hline
\end{tabular}

* ND: not determined

Table 2 Results obtained for drop collapse test, oil spreading test and emulsifier capacity for different chemical and biological surfactants used in this study 
O/W emulsions stabilized by the surfactants under study after 1 day and 15 days of emulsion formation.

\subsection{Drop collapse test}

In terms of drop collapse test, the results showed that the undiluted biosurfactant extract from CSL (pure) gave the greater diameter, whereas the diameter in less concentrated solutions ( 0.900 and $0.500 \mathrm{mg} \mathrm{mL}^{-1}$ ) was decreasing. The same behavior was observed in the case of biosurfactant from L. pentosus, where higher concentrations of biosurfactant gave higher diameters. Furthermore, both biological surfactants at nine times above their CMC, gave comparable results with the behavior of the non-ionic chemical surfactants under study, Tween 20 and Tween 80 (see Table 2 and Fig. 3).

Some authors $[23,24]$ have observed that there exists a correspondence between the surface tension capacity reduction of surfactants and their droplet diameters. Therefore, lower droplets diameters should correspond with a surfactant that produces lower surface tension reductions. Biosurfactant from CSL, was able to reduce the surface tension of media in 32 units, while the one extracted from L. pentosus, about 28 units. On the other hand, Tween 20 and Tween 80 were able to reduce the surface tension in 36 and 32 units respectively. It was observed that although Tween 20 and Tween 80 produced a slightly higher surface tension reduction of water than the biological surfactants they gave simi-

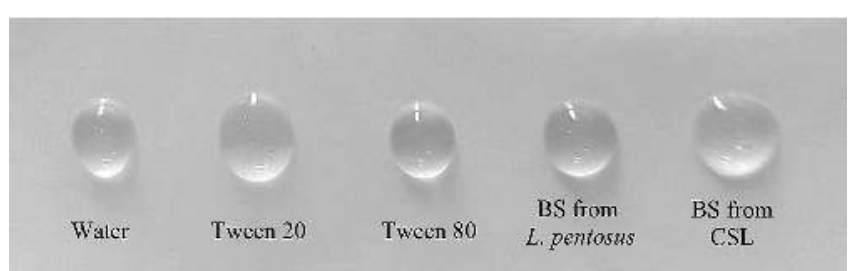

(a)

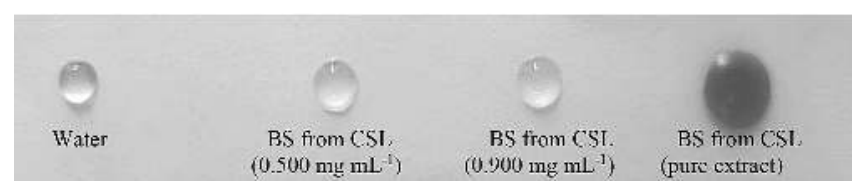

(b)

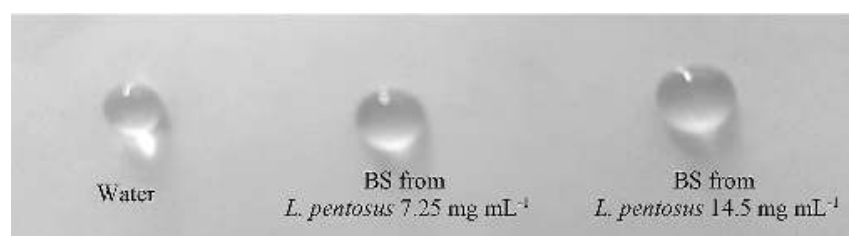

(c)

Figure 3 Drop collapse comparison between water, Tween 20 at $0.540 \mathrm{mg}$. $\mathrm{mL}^{-1}$, Tween 80 at $0.135 \mathrm{mg} \mathrm{mL}^{-1}$, L. pentosus biosurfactant at $14.5 \mathrm{mg} \mathrm{mL}^{-1}$ and biosurfactant from CSL at $0.900 \mathrm{mg} \mathrm{mL}^{-1}$, respectively (a). Drop collapse test of different biosurfactant concentrations from CSL comparing with water (b). Drop collapse test of different biosurfactant concentrations from L. pentosus comparing with water (c).

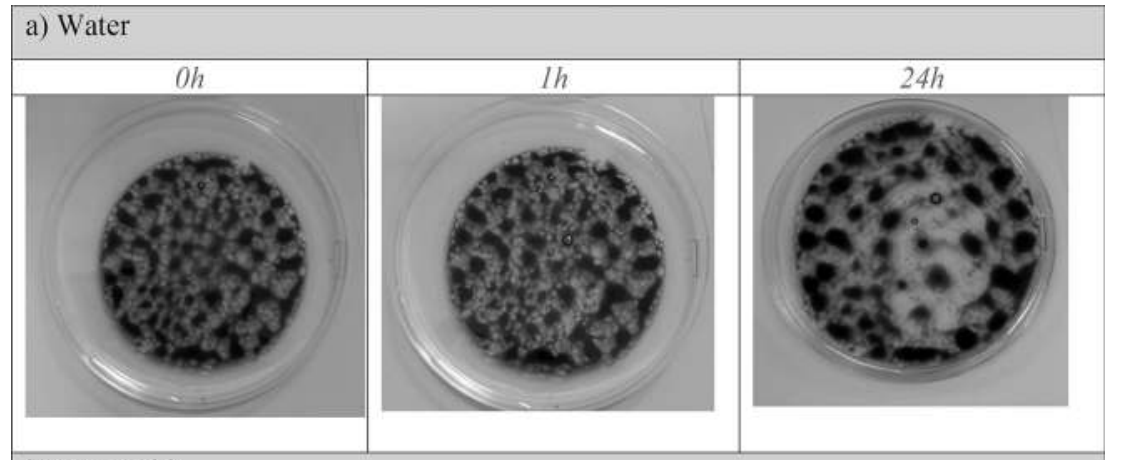

b) Tween 20
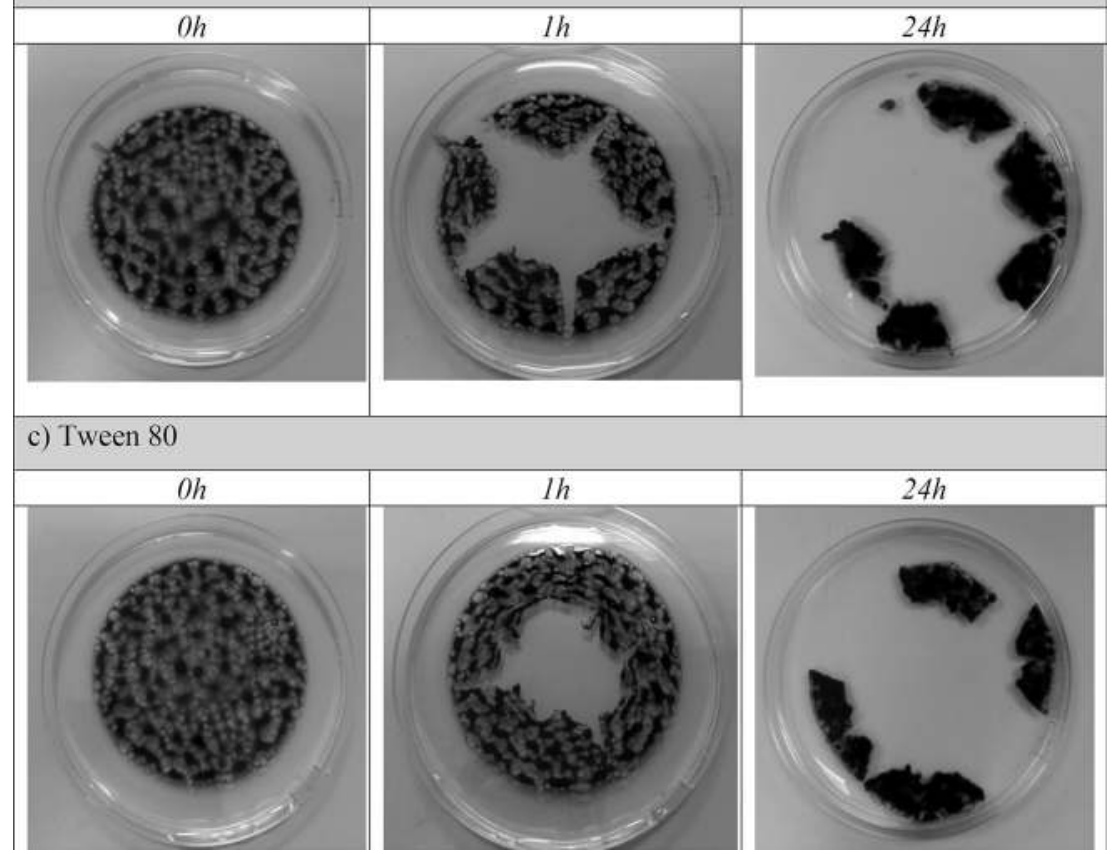

Figure 4 Oil spreading test for different surfactants at time 0 , after $1 \mathrm{~h}$ and after $24 \mathrm{~h}$ for: (a) control with water, (b) Tween 20 and (c) Tween 80. 
lar droplet diameters, when they were compared at the same concentration regarding their respective CMC values.

\subsection{Oil spreading test}

The way in which oil spreads over a surface of distilled water, can also give information about the surfactant or solubilizing capacity of the synthetic and biological surfactants evaluated in this work. Therefore, juniper oil was chosen as the hydrophobic phase because of its dark color, which allowed a better observation of the clear areas formed, in comparison with other oils used in cosmetic products, such as olive oil for example [28]. In this way, the same biosurfactant extracts and concentrations evaluated during the drop collapse test were used, comparing the dispersion capacity of the surfactants under evaluation after $1 \mathrm{~h}$ and $24 \mathrm{~h}$ in comparison with a negative control based on distilled water (Table 2 and Fig. 4 to Fig. 6). Regarding the diameter of clear zones produced after $1 \mathrm{~h}$ by the surfactants on juniper oil, Tween 20 gave zones having the highest diameter followed by the $L$. pentosus biosurfactant and the biosurfactant from CSL; whereas tween 80 produced lower clear zones. As it can be observed, in Fig. 4-6, biological surfactants showed similar, and in same cases even better, results than those ob-
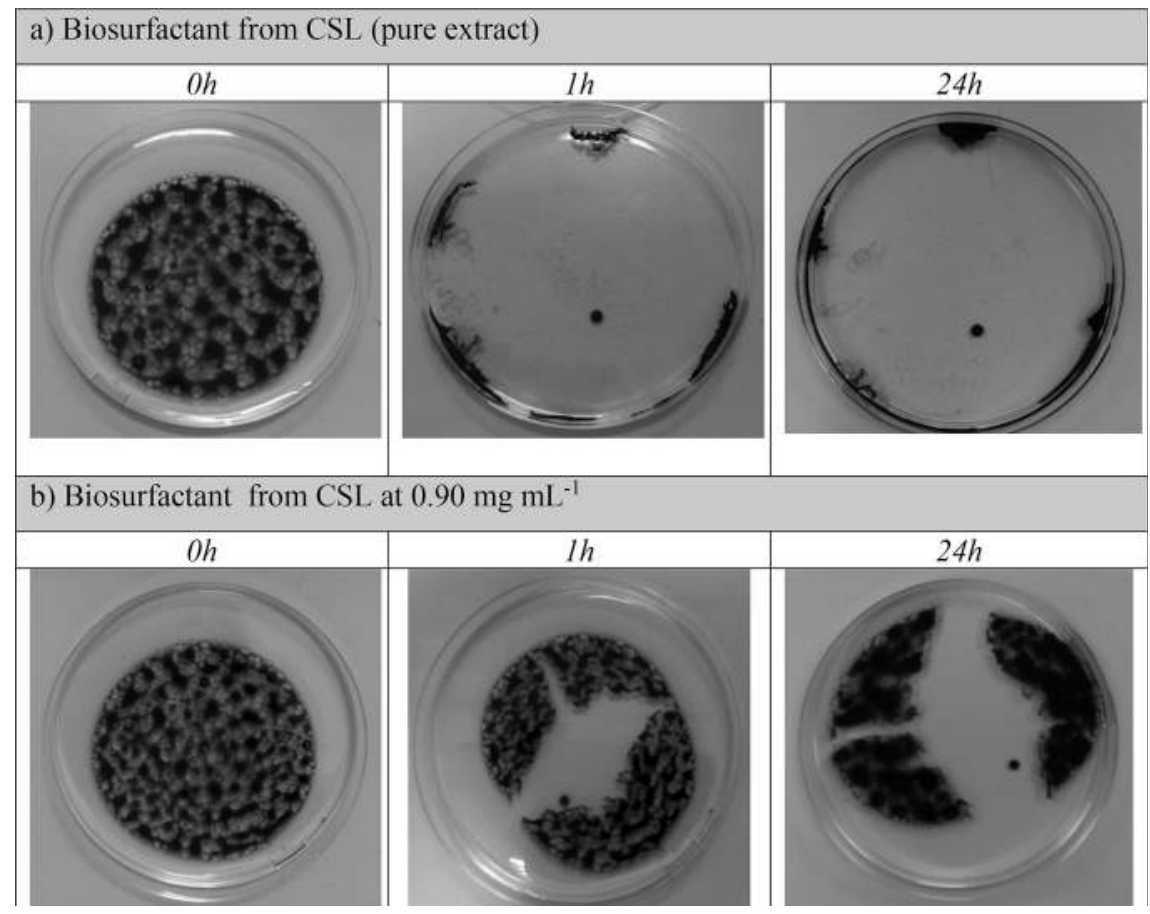

a) Biosurfactant from L. pentosus $7.25 \mathrm{mg} \mathrm{mL}^{-1}$
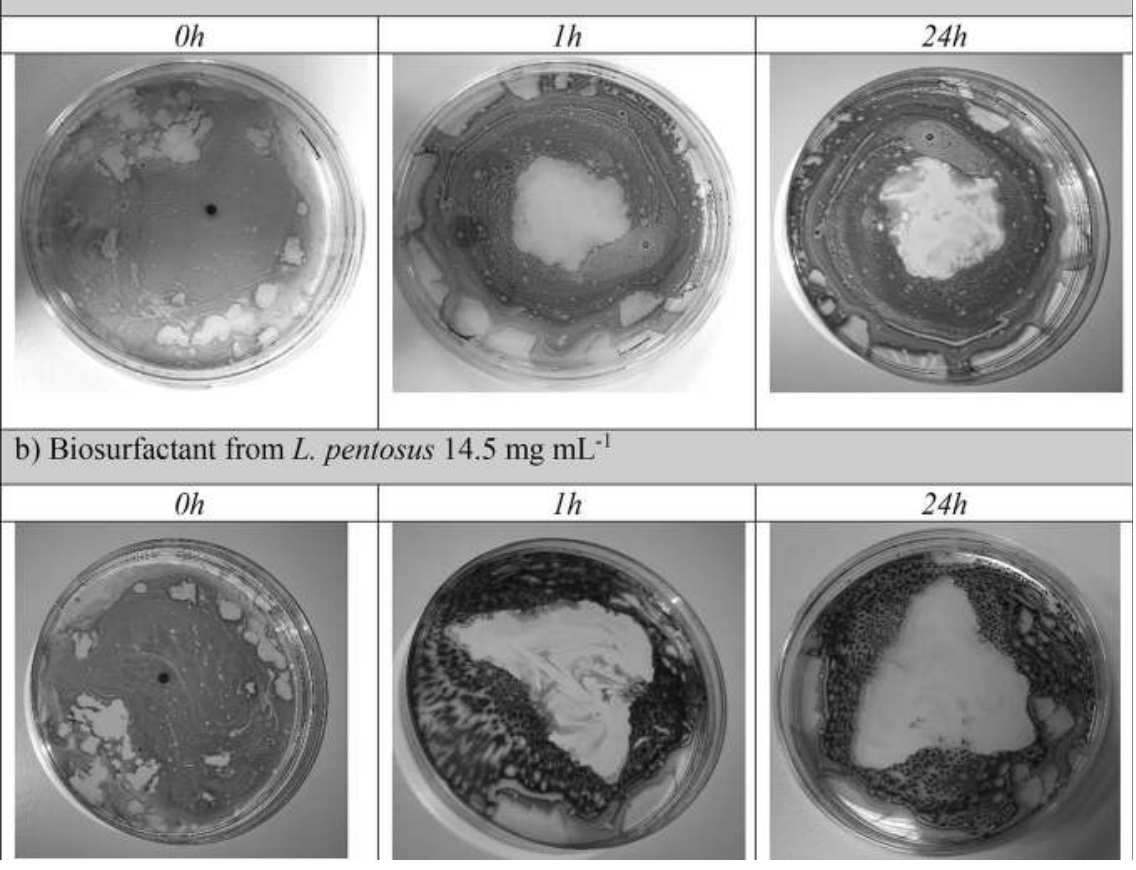

Figure 5 Oil spreading test at time 0 , after $1 \mathrm{~h}$ and after $24 \mathrm{~h}$ for (a) undiluted biosurfactant from $\mathrm{CSL}$ and (b) biosurfactant from CSL at $0.90 \mathrm{mg}$ $\mathrm{mL}^{-1}$.
Figure 6 Oil spreading test at time 0 , after $1 \mathrm{~h}$ and after $24 \mathrm{~h}$ for (a) biosurfactant from L. pentosus at $7.25 \mathrm{mg} \mathrm{mL}^{-1}$ and (b) biosurfactant from L. pentosus at $14.5 \mathrm{mg} \mathrm{mL}^{-1}$. 
tained with the chemical surfactants, which is in agreement with the results achieved with the drop collapse assay described above. Furthermore, after $24 \mathrm{~h}$, an increase in the diameter of clear zones produced for all the surfactants under evaluation was observed, except for the biosurfactant produced from L. pentosus that kept the same clear area. At that time, the chemical surfactants gave higher clear areas than the biological surfactants (see Table 2).

In comparison with other biosurfactants reported in the literature, it was observed that the biosurfactant obtained from CSL produced more clear areas on juniper oil than those obtained by other biosurfactants produced, for instance by Lactobacillus plantarum or Lactococcus lactis, tested on crude oil [29, 30]. However, biosurfactant from L. pentosus was less effective.

\section{Conclusions}

Based on the results obtained in this work, it was observed that biological surfactants could compete with chemical surfactants like polysorbates, to be included in pharmaceutical and cosmetic formulations. It was observed that the biosurfactant produced from $L$. pentosus showed better emulsify activity than polysorbates, whereas biosurfactant obtained from corn steep liquor, a residual stream of corn milling industry, showed a behavior closer to polysorbates regarding their capacity to disperse oil on water, although in terms of surface tension reduction, the biological surfactant gave similar activities than polysorbates. The characteristics of biosurfactant from corn stream are very similar to polysorbates, while the properties and characteristics of biosurfactant from L. pentosus are different in comparison with the chemical and biological surfactants under evaluation with a better emulsifier activity.

\section{Acknowledgements}

This study was supported by the Spanish Ministry of Economy and Competitiveness (MINECO) under the project CTM2015 68904 (FEDER funds) and by the Xunta de Galicia under project ED431B 2017/77. X. Vecino acknowledges MINECO for funding through a Juan de la Cierva contract (FJCI-2014 19732). L. Rodríguez-López acknowledges to the Spanish Ministry of Education, Culture and Sport for her pre-doctoral fellowship (FPU15/00205). M. Rincón-Fontán expresses her gratitude to University of Vigo for her pre-doctoral scholarship.

References

1. Han, S. B., Kwon, S. S., Jeong, Y. M., Yu, E. R. and Park, S. N.: Physical characterization and in vitro skin permeation of solid lipid nanoparticles for transdermal delivery of quercetin. Int I Cosmet Sci. 36 (2014) 588-597. PMid:25220288; DOI: 10.1111/ics.12160

2. Chate, V. M., Lewis, S. A., Prabhu, P., Dubey, A. and Patel, N.: Nanostructured lipid carriers for the topical delivery of tretinoin. Eur J Pharm Biopharm. 108 (2016) 253-261. PMid:27519827; DOI: 10.1016/j.ejpb.2016.07.026

3. Penfold, J., Thomas, R. K., Li, P. X., Petkov, J. T., Tucker, I. Webster, J. R. P. and Terry, A. E.: Adsorption at Air-Water and Oil-Water Interfaces and Self-Assembly in Aqueous Solution of Ethoxylated Polysorbate Nonionic Surfactants. Langmuir. 31 (2015) 3003-3011. PMid:25697294; DOI: 10.1021/acs.langmuir.5b0015

4. European Chemicals Agency, No Title, (n.d.). https://echa.europa.eu/es/ information-on-chemicals/cl-inventory-database/-/discli/details/69429.

5. Neuwirth, N. and Püringer J.: CLP Minimum classifications raise issues concerning occupational safety and health. Chemikalienrecht. 76 (2016) 107 114.

6. Vecino, X., Cruz, J. M., Moldes, A. B. and Rodrigues, L. R.: Biosurfactants in cosmetic formulations: trends and challenges. Crit Rev Biotechnol. 37 (2017) 911 - 923. PMid:28076995; DOI: 10.1080/07388551.2016.1269053

\section{0 - 12 OCTOBER 2018}

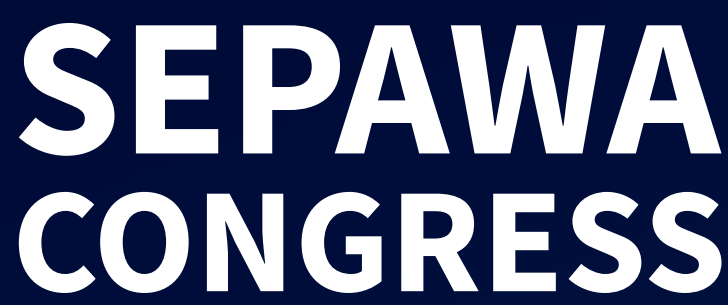

AND EUROPEAN DETERGENTS CONFERENCE ESTREL CONGRESS \& EXHIBITION CENTER | BERLIN

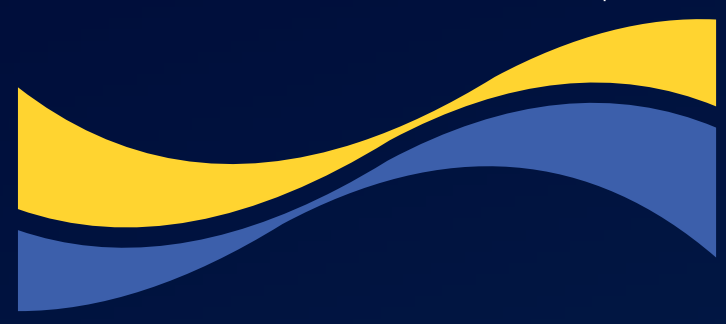
Scientific Program is now online!

Discover our new Fragrance Section. \#SEPAWA2018

www.sepawa-congress.com 
7. Vecino, X., Rodríguez-López, L., Cruz, J. M. and Moldes, A. B.: 2015. Sewage Sludge Polycyclic Aromatic Hydrocarbon (PAH) Decontamination Technique Based on the Utilization of a Lipopeptide Biosurfactant Extracted from Corn Steep Liquor. J Agric Food Chem. 63 (2015) 7143-7150. PMid:26206325; DOI:10.1021/acs.jafc.5b02346

8. Gharaei-Fathabad, E.: Biosurfactants in pharmaceutical industry: A mini-review. Am J Drug Discov Dev. 1 (2011) 58-69. DOI:10.3923/ajdd.2011.58.69

9. Gudiña, E. J., Teixeira, J. A. and Rodrigues, L. R.: Biosurfactants produced by marine microorganisms with therapeutic applications. Mar Drugs. 14 (2016) 38 - 53. PMid:26901207; DOI:10.3390/md14020038

10. Chen, J., Wu, Q., Hua, Y., Chen, J., Zhang, H. and Wang, H.: Potential applications of biosurfactant rhamnolipids in agriculture and biomedicine. Appl Microbiol Biotechnol. 101 (2017) 8309-8319. PMid:29018916; DOI: 10.1007/s00253-017-8554-4

11. Rodríguez-López, L., Vecino, X., Barbosa-Pereira, L., Moldes, A. B. and Cruz, J. M.: A multifunctional extract from corn steep liquor: antioxidant and surfactant activities. Food Funct. 7 (2016) 3724-3732. PMid:27492045; DOI:10.1039/C6FO00979D

12. Marchant, R. and Banat, I. M.: Biosurfactants: A sustainable replacement for chemical surfactants? Biotechnol. Lett. 34 (2012) 1597- 1605. PMid:22618240; DOI:10.1007/s 10529-012-0956-x

13. Elshikh, M., Moya-Ramírez, I., Moens, H., Roelants, S., Soetaert, W., Marchant, R. and Banat, I. M.: Rhamnolipids and lactonic sophorolipids: natural antimicrobial surfactants for oral hygiene. J Appl Microbiol. 123 (2017) $1111-1123$. PMid:28766815; DOI:10.1111/jam.13550

14. Paulino, B. N., Pessôa, M. G., Mano, M. C. R., Molina, G., Neri-Numa, I. A. and Pastore, G. M.: Current status in biotechnological production and applications of glycolipid biosurfactants. Appl Microbiol Biotechnol. 100 (2016) 1026510293. PMid:27844141 : DOl: 10.1007/s00253-016-7980-z

15. Mnif, I., Hammami, I., Triki, M. A., Azabou, M. C., Ellouze-Chaabouni, S. and Ghribi, D.: Antifungal efficiency of a lipopeptide biosurfactant derived from Bacillus subtilis SPB1 versus the phytopathogenic fungus, Fusarium solani. Environ Sci Pollut Res. 22 (2015) 18137 - 18147. PMid:26178831; DOI:10.1007/s 11356-015-5005-6

16. Portilla-Rivera, O. M., Torrado-Agrasar, A., Carballo, J., Domínguez, J. M. and Moldes, A. B.: Development of a factorial design to study the effect of the major hemicellulosic sugars on the production of surface-active compounds by L. pentosus. J Agric Food Chem. 57 (2009) 9057-9062. PMid: 19807160; DOI: $10.1021 / \mathrm{j} f 9014872$

17. Vecino, X., Bustos, G., Devesa-Rey, R., Cruz, J. M. and Moldes, A. B.: Salt-free aqueous extraction of a cell-bound biosurfactant: A kinetic study. J Surfactants Deterg. 18 (2015) 267-274. DOI:10.1007/s11743-014-1637-7

18. Vecino, X., Barbosa-Pereira, L., Devesa-Rey, R., Cruz, J. M. and Moldes, A. B.: Study of the surfactant properties of aqueous stream from the corn milling industry. J Agric Food Chem. 62 (2014) 5451 -5457. PMid:24877695; DOI: $10.1021 /$ j5501386 h

19. Portilla-Rivera, O., Torrado, A., Domínguez, J. M. and Moldes, A. B.: Stability and emulsifying capacity of biosurfactants obtained from lignocellulosic sources using Lactobacillus pentosus. J Agric Food Chem. 56 (2008) 8074 8080. PMid:18707111; DOI:10.1021/jf801428x

20. Vecino, X., Barbosa-Pereira, L., Devesa-Rey, R., Cruz, J. M. and Moldes, A. B.: Optimization of extraction conditions and fatty acid characterization of Lactobacillus pentosus cell-bound biosurfactant/bioemulsifier. J Sci Food Agric. 95 (2015) 313-320. PMid:24798413; DOI:10.1002/jsfa.6720

21. Vecino, X., Barbosa-Pereira, L., Devesa-Rey, R., Cruz, J. M. and Moldes, A. B.: Optimization of liquid-liquid extraction of biosurfactants from corn steep liquor. Bioprocess Biosyst Eng. 38 (2015) 1629 - 1637. PMid:25911424; DOI: 10.1007/s00449-015-1404-9

22. Hait, S. K. and Moulik, S. P.: Determination of critical micelle concentration (CMC) of nonionic surfactants by donor-acceptor interaction with lodine and correlation of CMC with hydrophile-lipophile balance and other parameters of the surfactants. J Surfactants Deterg. 4 (2001) 303-309. DOI: 10.1007/s1 1743-001-0184-2

23. Tugrul, T. and Cansunar, E: Detecting surfactant-producing microorganisms by the drop-collapse test. World J Microbiol Biotechnol. 21 (2005) 851 -853. DOI:10.1007/s11274-004-5958-y

24. Cornea, C. P., Roming, F. I., Sicuia, O. A., Voaideș, C., Zamfir, M. and Grosu-Tudor, S. S.: Biosurfactant production by Lactobacillus spp. strains isolated from Romanian traditional fermented food products. Romanian Biotechnological Letters. 21 (2016) 11312- 11320.

25. Rincón-Fontán, M., Rodríguez-López, L., Vecino, X., Cruz, J. M. and Moldes, A. B.: Design and characterization of greener sunscreen formulations based on mica powder and a biosurfactant extract. Powder Technol. 327 (2018) 442 448. DOI:10.1016/j.powtec.2017.12.093
26. Berns, R. S.: Billmeyer and Saltzman's Principles of Color Technology, 3er ed. New York (2000).

27. Völz, H. G.: Industrial Color Testing. Wiley-VCH Verlag GmbH \& Co. KGaA (2001). DOI:10.1002/3527600485.ch 1

28. Tserennadmid, R., Takó, M., Galgóczy, L., Papp, T., Vágvölgyi, C., Gero, L. and Krisch, J.: Antibacterial effect of essential oils and interaction with food components. Open Life Sci. 5 (2010) 641-648. DOI: 10.2478/s 11535-010-0058-5

29. Madhu, A. N. and Prapulla, S. G.: Evaluation and functional characterization of a biosurfactant produced by Lactobacillus plantarum CFR 2194. Appl Biochem Biotechnol. 172 (2014) 1777- 1789. PMid:24258794; DOI: 10.1007/s 12010-013-0649-5

30. Rodrigues, L. R., Teixeira, J. A., van der Mei, H. C. and Oliveira, R. Physicochemical and functional characterization of a biosurfactant produced by Lac tococcus lactis 53. Colloids Surface B. 49 (2006) 79-86. PMid:16616461* DOI:10.1016/j.colsurfb.2006.03.003

Received: 22. 03. 2018

Revised: 10. 04. 2018

\section{Bibliography}

DOI 10.3139/113.110574

Tenside Surf. Det.

55 (2018) 4; page 273-280

(c) Carl Hanser Verlag GmbH \& Co. KG

ISSN 0932-3414

\section{Correspondence address}

\section{Prof Dr. Ana Belén Moldes}

Chemical Engineering Department

School of Industrial Engineering

Centro de Investigación Tecnológico Industrial (MTI), University of Vigo

Campus As Lagoas-Marcosende

36310 Vigo

Spain

E-Mail: amoldes@uvigo.es

\section{The authors of this paper}

L. Rodríguez-López is a PhD student in the Chemical Engineering Department at University of Vigo and her research involves the purification and characterization of biosurfactants obtained by biotechnology processes as well as their application on the cosmetic field.

M. Rincón-Fontán is a PhD student in the Chemical Engineering Department at University of Vigo and her studies involved the formulation and application of cosmetic and personal care products such as shampoos, creams among others, using the biosurfactant obtained from corn milling industry.

$X$. Vecino is a $\mathrm{PhD}$ in the Chemical Engineering Department at the Polytechnic University of Catalonia (UPC), and her research focuses on the development of membrane and/or adsorption technology processes for the treatment, separation and/or recovery of value-added resources.

A. B. Moldes is an Associate Professor of the Chemical Engineering Department at the University of Vigo and her research is based on the biotechnological production of natural compounds, such as biosurfactants, bioemulsifiers, lactic acid, among others, by using renewable carbon sources, for application in the pharmaceutical, biomedical, environmental and food industries.

J. M. Cruz is a Associate Professor and the Head of the Chemical Engineering Department at University of Vigo. He has a huge number of publications about the partment at University of Vigo. He has a huge number of publications about the
utilization of agro-industrial residues as well as on the production of high-value compounds like biosurfactants and antioxidants, and their application in the food, pharmaceutical and environmental industry. 